\title{
CONSIDERING THE ISSUE OF RENOVATING PUBLIC BUILDINGS WITH REFERENCE TO IN-KIND INVESTIGATIONS INTO WALL HEAT TRANSFER COEFFICIENTS
}

\author{
Robertas Volvačiovas, Zenonas Turskis, Česlovas Ignatavičius, Leonas Ustinovičius, Audrius Ruzgys \\ Vilnius Gediminas Technical University, Sauletekio al. 11, LT-10223 Vilnius, Lithuania
}

Received18 November 2012; accepted 01 February 2013

\begin{abstract}
This article raises the problem of high energy consumption stimulated by heating buildings and preparing hot water. The paper shortly revises the state of renovating public buildings in Lithuania. A number of scientists devote close attention to examining various aspects of building renovation (technical regulations on constructions, subsidies provided by the state, cost-effectiveness, factors influencing building renovation, etc.). The article presents a few studies by foreign scientists, lists factors that determine public building renovation (unsatisfactory indoor air hygiene and floor temperature, indoor relative humidity, indoor air velocity, indoor carbon dioxide concentration, physical deterioration of a large building, poor aesthetic appearance of the building, etc.) and demonstrates a few practical examples. In accordance with Lithuanian design codes, a methodology for determining heat transfer coefficients in public buildings is provided. Besides, investigations into heat transfer coefficients before and after the renovation of public buildings have been conducted. A few nursery school buildings in Lithuania have been examined applying laboratory equipment before and after renovation. It was found that the wall heat transfer coefficient of properly designed and insulated buildings falls by more than 4-5 times to reach the normal value of the heat transfer coefficient (value of the heat transfer coefficient falls from 1.12 to $0.22 \mathrm{~W} /\left(\mathrm{m}^{2} \cdot \mathrm{K}\right)$ ). A comparison of an external thermal insulation plastering composite system with an external aeration heat-insulated system has been done. The estimation has revealed that due to lower costs, better results of thermal resistance obtained using the external thermal insulation plastering composite system can produce better wall heat transfer coefficient values. The obtained results have been determined referring to better wall insulation tightness. The paper also summarizes data on heating buildings and consumption of prepared hot water before and after renovation. On the basis of the findings acquired employing the degree-day-method, public building energy consumption for heating and hot water preparation decreased from 41.30 to $43.73 \%$.
\end{abstract}

Keywords: public building, building renovation, building modernization, economic benefit, external partition, heat transfer coefficient, in-kind investigations, degree-day-method.

Reference to this paper should be made as follows: Volvačiovas, R.; Turskis, Z.; Ignatavičius, Č.; Ustinovičius, L.; Ruzgys, A. 2013. Considering the issue of renovating public buildings with reference to inkind investigations into wall heat transfer coefficients, Engineering Structures and Technologies 5(2): 82-91. http://dx.doi.org/10.3846/2029882X.2013.811783

\section{Introduction}

Recently, energy efficiency of buildings has been attracting more and more attention of researchers, policy-makers, experts and ordinary people, because energy consumption for heating and hot water makes up a large part of the population and state revenue.
These costs can be reduced in several ways: by lowering energy prices, which depend on the global market economy and political situation in the country, increasing energy production and heating route efficiency or designing and constructing (renovating) buildings with less energy consumption. Close attention should

Corresponding author:

R. Volvačiovas E-mail: robertas.volvaciovas@vgtu.lt 
be given to design and construction works and control over them in accordance with applicable technical regulations and requirements for building technology.

Currently, energy consumption in the buildings of the European Union (EU) members seeks approximately $40 \%$. It has been established that energy consumption for heating exceeds $150-200 \mathrm{kWh} / \mathrm{m}^{2}$ per year for old buildings in Lithuania, whereas for new constructions - ranges $55-60 \mathrm{kWh} / \mathrm{m}^{2}$ and for passive buildings does not exceed $15 \mathrm{kWh} / \mathrm{m}^{2}$ per year (Endriukaityte 2009).

Since 2018, public buildings and since 2020, all new-construction buildings in the EU will become almost zero energy consumption buildings. Also, the member states should prepare national plans to increase the amount of nearly zero energy consumption buildings, and the major part of energy demand must come from renewable sources, including in site or nearby produced renewable energy (EU Council 2009).

Due to current speculations on building renovation, it is important to perform scientific investigations for the purpose of demonstrating the effectiveness of renovation and uncovering the existing shortcomings. The aim of the article is to determine how effectively Lithuanian public buildings are renovated (designing and carrying out construction work), taking into account a decrease in wall heat transfer coefficients and economic benefits of the renovated buildings.

Foreign scientists devote full attention to investigation into building renovation problems. Galvin (2010) analyzed building renovation in Germany: technical regulations on construction, received subsidies and cost-effectiveness. Galvin focuses on investigating compensation for building renovation considering subsidies provided for building renovation and technical regulation of construction. Galvin offered recommendations to German politicians on how to improve the current situation on building renovation in the country. Weiss et al. (2012) also investigated the possible policy activity to improve the efficiency of building renovation in Germany. In order to reduce greenhouse gas emissions for building renovation in Germany, considerable attention has been devoted to wall and roof insulation as well as to the production of renewable energy used for heating buildings. Tommerup and Svendsen (2006) examined energy conservation in residential buildings in Denmark most of which (75\%) were built until 1979, when Denmark introduced the first important regulated legislation on energy efficiency. The authors showed how Danish technical regulations became stricter over the years thus indicating the heat transfer coefficient of an external partition. From 1930 and up to the present day, the normative value of the wall heat transfer coefficient has decreased more than 3 times and now is similar to the normative value of the heat transfer coefficient used in Lithuania. Residential buildings in Denmark were renovated complexly. Therefore, energy-saving measures have been implemented in a relatively inexpensive and cost-effective manner. Tuominen et al. (2012) investigated the existing energy-saving potential of the buildings and possible market obstacles in the EU. It was concluded that energy savings in the buildings of the EU member states could reach $10 \%$ up to 2020 and $20 \%$ up to 2030 . The situation when funds invested in renovation fail to proportionally increase the real estate values is the main reason for a refusal to renovate buildings. Another problem is that energy prices do not consider all real costs, for example, pollution taxes in one or another country. Nair et al. (2010) analyzed factors affecting building renovation in Sweden. Personal characteristics of the population, including population age, income, education, etc. as well as building-related factors such as the age of the building, thermal discomfort, past investments, etc. were investigated and showed that energy prices had the greatest influence on people renovating buildings. Cakmanus (2007) investigated building energy consumption and conservation problems in Turkey where buildings consume up to 2 times more energy than the buildings in other European countries. The authors examined the buildings constructed in 1988 in the capital city Ankara. The conducted research has shown that overall building energy demand could be reduced by up to $47 \%$. In recent decades, many European countries have been updated technical regulations on construction; such activity has been intensive so far, as for some specific European countries the problems of energy consumption have remained to be of a pressing character. Papadopoulos et al. (2002) justifies the need for renovating buildings in Greece. Climatic conditions in the northern part of the country are worse: the heating season is the longest and coldest. For a long time, there has been less investment in energy-saving measures due to low energy prices in Greece; however, due to a rise in fuel costs, it has been accepted that there is lack of attention in this area. Thereby, the renovation of public buildings in Greece is started and will serve a 
good example for the renovation of multifamily housing. Alanne (2004) describes alternatives for selecting the options of building renovation and potential problems as well as presents the availability of a mathematical model for selecting technological solutions to building renovation. Effective selection of alternatives refers to calculation that simplifies decision-making. Currently, a wide range of new technological solutions are offered and can be used for improving the quality of building lifetime, and therefore an effective selection of alternatives has become a burning issue.

These are the conceptions (definitions) used in the article:

Public building is a building intended to public needs taking into account provisions for STR 1.01.09:2003 that cover hotels, administrative buildings, trade buildings, service buildings, catering buildings, transport buildings, culture buildings, education buildings, health care buildings, recreation buildings, sports buildings and religious buildings (STR 2.02.02:2004).

Building renovation (modernization) embraces construction works that renew or improve buildings and (or) its physical and energetic properties of engineering systems and (or) ensure energy consumption from renewable energy sources (Construction Law of the Republic of Lithuania 1996).

\section{Condition for renovating public buildings in Lithuania}

Public buildings in Lithuania are renovated rather quickly, because a part of those (public institutions) have the ability to receive up to $100 \%$ of financial support for the repair and reconstruction of external walls and modernization of building energy systems from EU structural support funds and the Government of the Republic of Lithuania. 314.61 million $€$ was provided for renovation works for the period 2007-2013, while in April 2012, the assigned financing reached the rate of 273.70 million $€(87.00 \%)$. Presently, 322 objects have been already renovated and 177 have only been started (EU support 2012). Not all public buildings are state-owned, for example, the buildings of hotels, administrative buildings, trading buildings, service buildings, catering buildings, recreation buildings, sports buildings. These are also renovated in Lithuania, though using private funds not the EU structural funds. The Department of Statistics to the
Government of the Republic of Lithuania does not provide data on the number of renovated private public buildings and the amount of money invested in this renovation. The institution presents data on how much work has been done on their own according to the types of construction works. For example, 522.65 million $€$ was spent for repair and restoration works (including building renovation) in 2011 using EU structural support funds, allowances from the budget of the Republic of Lithuania and private funds (Department of Statistics of the Republic of Lithuania 2012). Hence, it can be assumed that private fund investments into renovation are several times greater than those made by the EU structural support funds and the Government of the Republic of Lithuania. Lithuania has also done relatively less construction works comparing to the EU (about $0.25 \%$ ), which only indicates that the EU developed countries receive greater attention to the renovation of public buildings (Eurostat 2012).

\section{Factors influencing the renovation of public buildings}

Many of the existing problems must to be solved to renovate public etc. buildings. In each case, the problems retain an individual character and are typical of a particular building. However, according to the studies performed by the authors, the following problems can be noted:

1. Indoor air temperature $\left({ }^{\circ} \mathrm{C}\right)$ is too low or too high.

2. Difference in indoor temperature $\left({ }^{\circ} \mathrm{C}\right)$ at 0.10 and $1.10 \mathrm{~m}$ above the floor is too high.

3. Floor temperature $\left({ }^{\circ} \mathrm{C}\right)$ is too low.

4. Indoor relative humidity (\%) is too low or too high.

5. Indoor air velocity $(\mathrm{m} / \mathrm{s})$ is too high.

6. Carbon dioxide $\left(\mathrm{CO}_{2}\right)$ concentration (\%) is too high.

7. Consumption of heating, hot water preparation and electric energy $(\mathrm{kWh})$ is high.

8. Large physical deterioration of the building (\%): building structures, windows, doors, internal engineering systems of the building.

9. Poor aesthetic appearance of the building.

According to Lithuanian Hygiene Norm HN 42:2009 (microclimate of residential and public buildings), the limit values of the indoor microclimate parameters of the building are the optimal values of the 
microclimate parameter having no negative effects on the state of health in the environment (HN 42:2009).

The above introduced problems appear due to the thermal resistance of low floors, walls, roofs, windows and doors, improper ventilation, building uneconomic decisions, poor building maintenance and other reasons.

The authors investigated a number of public buildings (nursery schools) before and after renovation:

1. Nursery school Ežerèlis in Trakai.

2. Nursery school in Semeliškès.

3. Nursery school in Lentvaris.

4. Nursery school Saulute in Molètai.

A few test results can be presented as practical examples of the above mentioned problems. For instance, the measured indoor air temperature in some rooms of the nursery school in Lentvaris was too low while in other rooms was too high (see Fig. 1). The problem is due to an improperly designed and operated heating system of the building. The limit values of indoor microclimate parameters for investigating nursery schools are provided in Lithuanian Hygiene Norm HN 42:2009 (indoor microclimate of residential and public buildings (HN 42:2009)), Lithuanian Hygiene

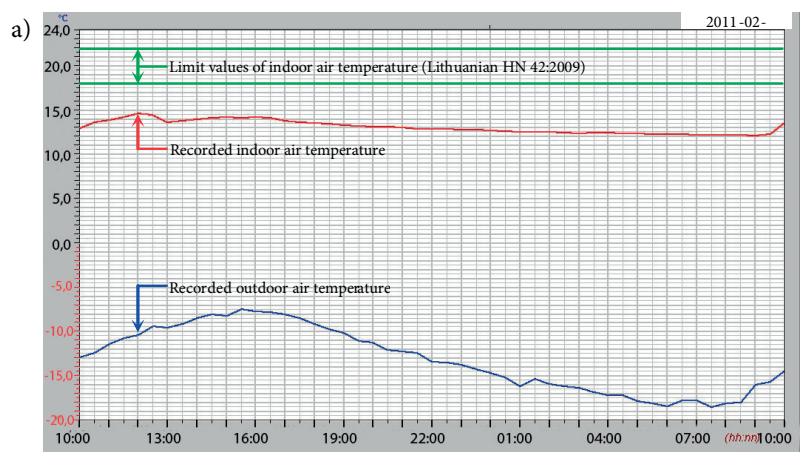

b)

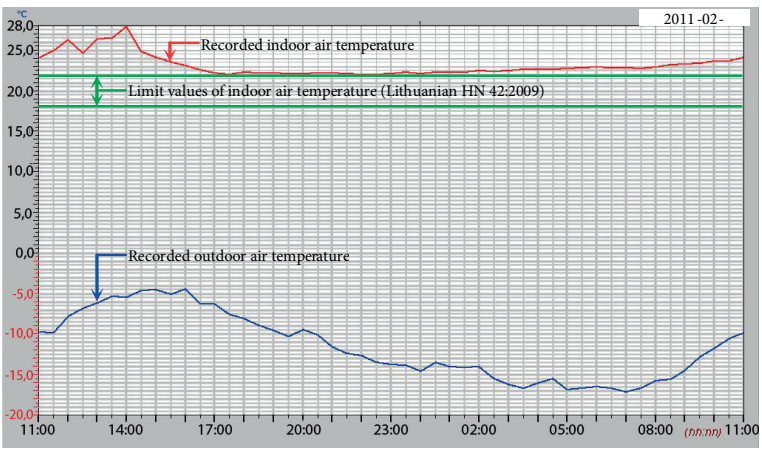

Fig. 1. Outdoor and indoor air temperatures recorded in different groups of nursery schools: a) 2011-02-24 $\div 25$;

b) $2011-02-25 \div 26$
Norm HN 75:2010 (institution executing preschool educational programs and general health and safety requirements (HN 75:2010)).

As shown in Figure 1, air temperature in the first room (nursery group number 11) ranges from 12 to $15{ }^{\circ} \mathrm{C}$, whereas in the second room (nursery group number 1) - from 22 to $28{ }^{\circ} \mathrm{C}$. Air temperature in these rooms does not agree with the requirements of Lithuanian Hygiene Norm, as indoor air temperature in the cold season may vary in the range of $18-22^{\circ} \mathrm{C}$. During the study, outside air temperature ranged from -4 to $-19^{\circ} \mathrm{C}$. Indoor air temperature was recorded in every room all days using a metrological verified laboratory apparatus - data storage device "ALMEMO 2890-9 Ahlborn" equipped with internal temperature and relative humidity measurement probes FH A646-E1.

\section{Investigations into the wall heat transfer coefficients of public buildings before and after renovation}

STR 2.05.01:2005 'thermal technique for building partition' provisions must be applied for designing new and reconstructed buildings in Lithuania. The normative heat transfer coefficient of public building walls, according to this provision, is equal to

$$
U_{N}=0.25 \cdot \kappa,
$$

where $\kappa=20 /\left(\Theta_{i}-\Theta_{e}\right)$ - temperature adjustment, $\Theta_{i}-$ indoor air temperature, ${ }^{\circ} \mathrm{C}, \Theta_{e}-$ mean outdoor air temperature at the heating season, ${ }^{\circ} \mathrm{C}$. The values of $\Theta_{e}$ are taken from RSN 156-94 (1995) Table 2.6, or STR 2.09.04:2008 Capacity of the Heating System. Demand for heating is taken from Annex 9, Table 9.2.

The heat transfer coefficient of the partition $(U)$ is the density of heat flux passing through the partition, when difference in air temperature on both sides of the partition is $1 \mathrm{~K}\left[\mathrm{~W} /\left(\mathrm{m}^{2} \cdot \mathrm{K}\right)\right]$ (STR 2.05.01:2005). The most frequently used term 'thermal resistance' is the value inverse to the heat transfer coefficient.

Two of the four buildings investigated by the authors of this paper were finally renovated before April 2012:

1. Nursery school in Semeliškès (see Fig. 2).

2. Nursery school Saulute in Molètai (see Fig. 3). The nursery school in Semeliškes was built in 1980, and the total area of the building is $478.60 \mathrm{~m}^{2}$. This is a one-storey reinforced concrete frame building with a local diesel fuel boiler fitted in the basement. The porous concrete slabs of $240 \mathrm{~mm}$ were used for the 

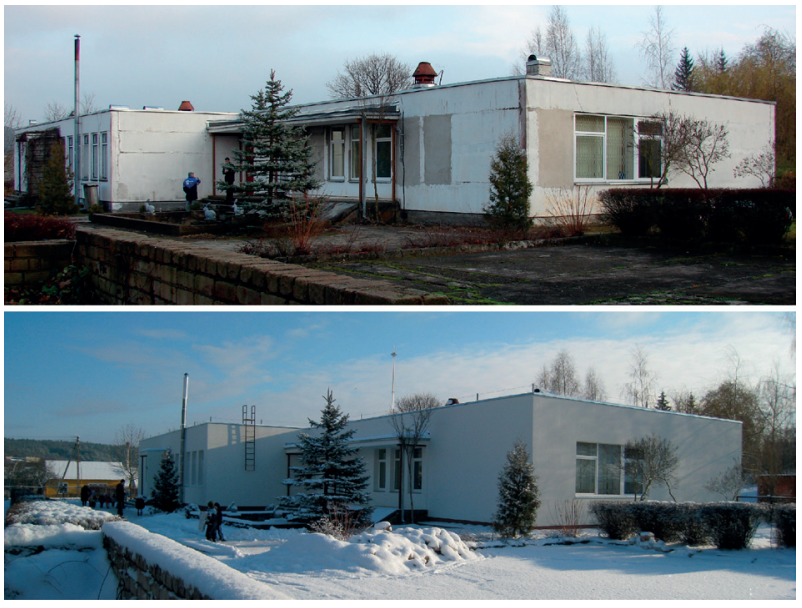

Fig. 2. Nursery school in Semeliškès before and after renovation

external wall of the building, and the base was made of $200 \mathrm{~mm}$ thick reinforced concrete blocks. Interior and exterior walls were plastered and painted. During renovation in 2011, the walls of the building were insulated with $120 \mathrm{~mm}$ mineral wool panels (mineral plasters and silicate paints were used for finishing). The base was insulated with $100 \mathrm{~mm}$ thick extruded polystyrene foam slabs (EPS 80). Mineral plasters and silicate paints were used for finishing the base (see Fig. 2).

Nursery school Saulute in Moletai was built in 1982 and the total area of the building is $2460.18 \mathrm{~m}^{2}$. This is a two-storey reinforced concrete frame building with a heat substation to the central heating boiler from the block in the basement. The porous concrete slabs of $240 \mathrm{~mm}$ with finishing of granite plaster were used for the external wall of the building and the base was made of $200 \mathrm{~mm}$ thick reinforced concrete blocks. Interior and exterior walls were plastered and painted. During renovation in 2011, the walls of the building were insulated with $150 \mathrm{~mm}$ mineral wool panels (using an external aeration heat-insulated system with facade decorative panels). The base was insulated with $75 \mathrm{~mm}$ thick extruded polystyrene foam slabs (EPS 100). Stone mass tiles were used for finishing the base (see Fig. 3).

During the examination of these buildings, physical deterioration before renovation has been determined according to Russian methodology BCH 53-86 (p) published in 1988. This methodology was created specifically for assessing the physical deterioration of the buildings constructed in the last century. With reference to this methodology, the deterioration of the nursery school in Semeliškess reached $25 \%$ and the nursery school Saulute in Molètai - 29\% (Matulis et al. 2012).

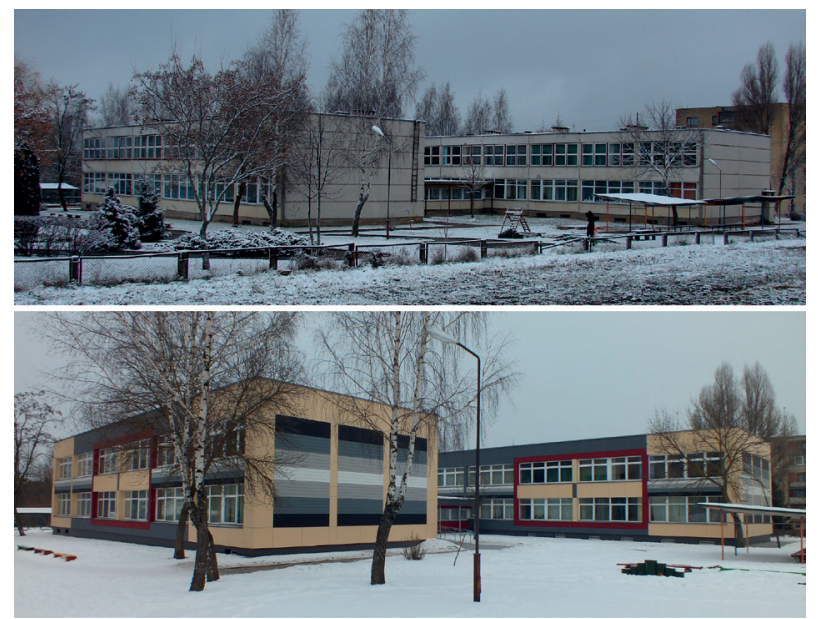

Fig. 3. Nursery school Saulutè in Molètai before and after renovation

Wall heat transfer coefficients of the investigated buildings were determined on the basis of in-kind investigation methodology according to which the heat transfer coefficient of the external partition was determined measuring heat flux, indoor air temperature and outdoor air temperature. The following expression was used:

$$
U=\frac{q}{\Theta_{i}-\Theta_{e}},
$$

where $q$ - the average value of the measured heat flux through the external partition, $\mathrm{W} / \mathrm{m}^{2}, \Theta_{i}$ - average indoor air temperature ${ }^{\circ} \mathrm{C}, \Theta_{e}-$ average outdoor air temperature, ${ }^{\circ} \mathrm{C}$.

Special laboratory measuring devices equipped with autonomous program control have been completed for this investigation. Heat flux was measured simultaneously at three points of the same partition due to accuracy (see Fig. 4). Heat flux and temperatures were measured every 30 minutes throughout the day. The measurement results obtained from the memory data storage device was read out to computer. To ensure the reliability of the measurement results of the examined partition, prerequisites are as follows:

1. All devices were connected at the same time at one characteristic point.

2. For connected devices, the collection and storage of data occur for at least one day.

3. The same data collection interval must be selected at all points under investigation.

4. Sustained temperature must be outside, sunlight and wind speed can affect results.

Heat conductivity of the partition was measured and stored in the measuring device Ahlborn Mess- und Regelungstechnik $\mathrm{GmbH}$ consisting of: 


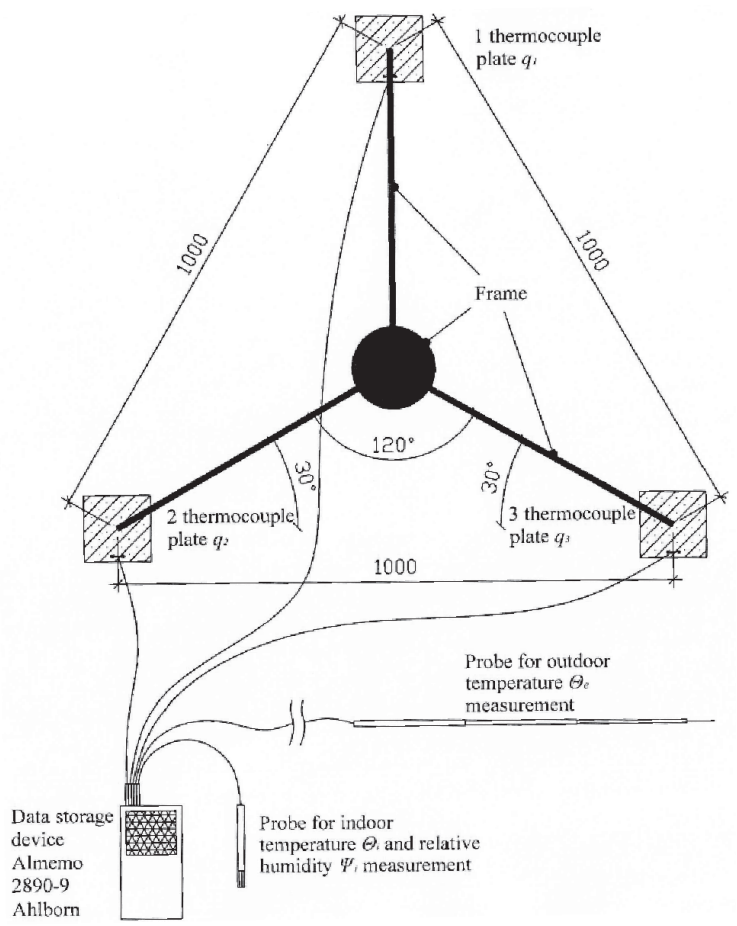

Fig. 4. Principal scheme for measuring heat fluxes of the walls

1. Data storage device ALMEMO $2890-9$ Ahlborn equipped with data memory measurement.

2. Thermocouple plates (probes) of the heat flux measurement of the partition (model FQA018CSI).

3. Probes of indoor temperature and relative humidity measurement (model FH A646-E1).

4. Probes of outdoor temperature measurement (model FTA05L0050).

The data (see Fig. 5, Table 1) have been obtained during investigation carried out before and after wall insulation. The diagrams of heat transfer coefficients (one daily measurement data) before wall insulation are shown in Fig. 5a and after wall insulation - in Fig. 5b while summary statistics has been presented in Table 1. According to the presented diagram of one of the rooms in the nursery school Saulute in Molètai (bedroom number 1-5), wall heat transfer coefficients before wall insulation were more than 4 times greater than the normative value given in the current building regulations imposed by the legal acts of the Republic of Lithuania while after insulation (the same wall), the mean value of heat transfer coefficients satisfies the building regulations stipulated by the law and does not exceed the normative values of the heat transfer coefficient $\left(U_{N}=0.25 \mathrm{~W} /\left(\mathrm{m}^{2} \cdot \mathrm{K}\right)\right)$.
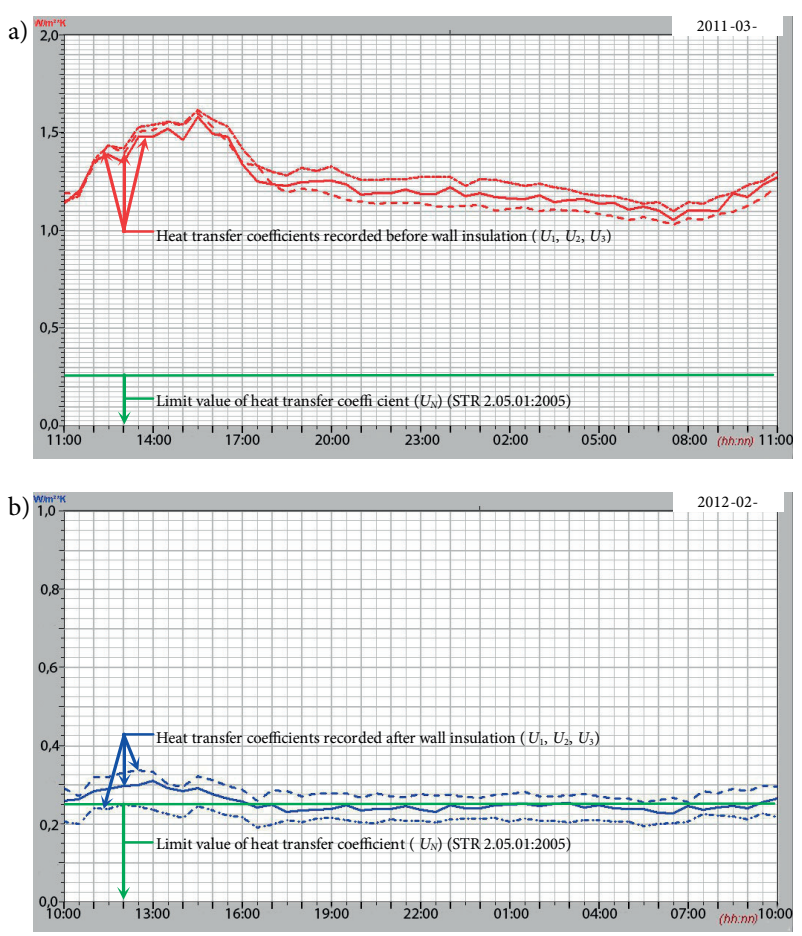

Fig. 5. Heat transfer coefficients recorded before and after wall insulation: a) $2011-03-03 \div 04$; b) $2012-02-13 \div 14$

The analyzed data (see Table 1) of two renovated nursery schools show that designers have attained the intended heat transfer coefficient values they wanted to obtain after wall insulation. However, the original existing values of the wall heat transfer coefficient predicted by designers differed from the actual ones measured applying laboratory equipment. The wall heat transfer coefficient $\left(U=1.12 \mathrm{~W} /\left(\mathrm{m}^{2} \cdot \mathrm{K}\right)\right)$ of the nursery school in Semeliškès was lower than that predicted by designers $\left(U=0.73 \mathrm{~W} /\left(\mathrm{m}^{2} \cdot \mathrm{K}\right)\right)$, and the wall heat transfer coefficient $\left(U=1.08 \mathrm{~W} /\left(\mathrm{m}^{2} \cdot \mathrm{K}\right)\right)$ of the nursery school Saulute in Moletai was higher than that predicted by designers $\left(U=1.19 \mathrm{~W} /\left(\mathrm{m}^{2} \cdot \mathrm{K}\right)\right)$.

The examination of different insulation systems of nursery schools revealed that better results were obtained applying external plastered composite thermal insulation systems (nursery school in Semeliškès), and worse results - employing external aeration heat-insulated systems (nursery school Saulutè in Moletai). The actual thermal condition of the wall in the nursery school in Semeliškès was worse than that in the nursery school Saulute in Molètai. However, using less investment (120 mm instead of $150 \mathrm{~mm}$ mineral wool used in other nursery school) helped in obtaining better values of heat transfer coefficients. Therefore, wall thermal resistance was higher in the nursery school 
in Semeliškès. These results are achieved due to better wall thermal insulation tightness.

The examination of economic benefits gained from renovated buildings and comparing energy consumption for heating of the last two heating seasons (before and after renovation) disclosed that the amount of purchased diesel fuel after building renovation in the nursery school in Semeliškès for heating purposes decreased by $25.73 \%$ from 8023.201 to 5958.701 during the heating season. Energy consumption for heating and hot water preparation after building renovation in the nursery school Saulute in Molètai decreased by $40.55 \%$ from 298.21 MWh to 177.29 MWh during the heating season. These calculations are preliminary and do not reflect the true economic benefit, as they underestimate an increase in indoor air temperature after building renovation and climatic conditions at different heating seasons. Obviously, the warmer is the climate the less energy is consumed in order to ensure indoor thermal comfort. At different time, there is a need to recalculate the cost of heating so that different costs to be as correct as possible for comparison purposes at different heating seasons under different climatic conditions. This is especially important in case you want to evaluate the benefits of heat-saving features. As one of the possible methods for solving this problem is the suggested degree-day-method.

The essence of the method lies in recalculating actually consumed energy into energy equivalent normative according to climate condition. The degree day is calculated as a product indicating the duration of the heating season (days) and the average difference in indoor and outdoor temperatures:

$$
D D_{f}=z \cdot\left(t_{i}-t_{o}\right),
$$

where $D D_{f}$ - the actual number of the degree day in the calculation area of the heating season, $z$ - duration of the heating season, days, $t_{i}$ - average design indoor air temperature, ${ }^{\circ} \mathrm{C}, t_{0}$ - average design outdoor air temperature, ${ }^{\circ} \mathrm{C}$.

As specific heat consumption during the heating season and the number of degree days is known, heating costs converted to normative conditions are found from the equation:

Table 1. Heat transfer coefficients before and after wall insulation

\begin{tabular}{|c|c|c|c|c|c|c|c|}
\hline \multicolumn{2}{|c|}{ Nursery school } & \multicolumn{6}{|c|}{ Heat transfer coefficient $U,\left[\mathrm{~W} /\left(\mathrm{m}^{2} \cdot \mathrm{K}\right)\right]$} \\
\hline \multirow{3}{*}{ Name } & \multirow{3}{*}{ Room } & \multicolumn{3}{|c|}{ Before renovation } & \multicolumn{3}{|c|}{ After renovation } \\
\hline & & \multirow{2}{*}{$\begin{array}{c}\text { Predicted by } \\
\text { designers }\end{array}$} & \multicolumn{2}{|l|}{ Actual } & \multirow{2}{*}{$\begin{array}{c}\text { Predicted by } \\
\text { designers }\end{array}$} & \multicolumn{2}{|l|}{ Actual } \\
\hline & & & At one measured point & Mean & & At one measured point & Mean \\
\hline \multirow{6}{*}{ Semeliškès } & \multirow{3}{*}{$\begin{array}{c}\text { Storehouse } \\
\text { No 1-28 }\end{array}$} & \multirow{7}{*}{0.73} & 1.21 & \multirow{3}{*}{1.30} & \multirow{7}{*}{0.22} & 0.24 & \multirow{3}{*}{0.23} \\
\hline & & & 1.48 & & & 0.21 & \\
\hline & & & 1.22 & & & 0.25 & \\
\hline & \multirow{3}{*}{$\begin{array}{l}\text { Bedroom } \\
\text { No } 1-29\end{array}$} & & 1.04 & \multirow{3}{*}{0.93} & & 0.19 & \multirow{3}{*}{0.20} \\
\hline & & & 0.94 & & & 0.24 & \\
\hline & & & 0.82 & & & 0.18 & \\
\hline \multicolumn{2}{|c|}{ Average: } & & \multicolumn{2}{|l|}{1.12} & & \multicolumn{2}{|l|}{0.22} \\
\hline \multirow{9}{*}{$\begin{array}{l}\text { Saulutè in } \\
\text { Molètai }\end{array}$} & \multirow{3}{*}{$\begin{array}{l}\text { Bedroom } \\
\text { No 1-5 }\end{array}$} & \multirow{10}{*}{1.19} & 1.18 & \multirow{3}{*}{1.20} & \multirow{10}{*}{0.25} & 0.24 & \multirow{3}{*}{0.24} \\
\hline & & & 1.27 & & & 0.28 & \\
\hline & & & 1.14 & & & 0.21 & \\
\hline & \multirow{3}{*}{$\begin{array}{l}\text { Bedroom } \\
\text { No 1-25 }\end{array}$} & & 1.06 & \multirow{3}{*}{1.10} & & 0.37 & \multirow{3}{*}{0.34} \\
\hline & & & 1.14 & & & 0.25 & \\
\hline & & & - & & & 0.40 & \\
\hline & \multirow{4}{*}{$\begin{array}{l}\text { Children's } \\
\text { playing and } \\
\text { sleeping } \\
\text { room } \\
\text { No 2-94 } \\
\text { age: }\end{array}$} & & 0.94 & \multirow{4}{*}{0.94} & & 0.15 & \multirow{3}{*}{0.17} \\
\hline & & & 0.89 & & & 0.15 & \\
\hline & & & 1.00 & & & 0.20 & \\
\hline Average: & & & 1.08 & & & 0.25 & \\
\hline
\end{tabular}




$$
Q_{n}=Q_{f} \cdot \frac{D D_{n}}{D D_{f}},
$$

where $Q_{n}$-annual heat consumption recalculated to normative, MWh, $Q_{f}$ - annual heat consumption, MWh, $D D_{n}$ - the number of degree days in the calculation area in the heating season of the normative year. The values of $D D_{n}$ are taken from RSN 156-94 (1995) Table 2.6 (Leka 2012).

According to the degree-day-method, energy savings in heating in the nursery school in Semeliškès was $41.30 \%$, while energy savings in heating and hot water preparation in the nursery school Saulute Moletai made $43.73 \%$ (comparing the last two heating seasons).

Currently, totally 76 nursery schools have been renovated in Lithuania (Ministry of Economy 2012).

Similar studies were carried out by the authors in residential buildings (houses) (Ignatavičius et al. 2007) and non-residential buildings (schools) (Ignatavičius et al. 2002).

\section{Conclusions}

1. In order to reduce energy consumption in renovated buildings, high priority should be given to design and construction works and their control, according to building technical regulations and requirements on construction technology.

2. Foreign scientists accept that for a long time less was invested into the energy saving measures for buildings, and only now that the costs of energy are rising, a lack of attention to this area was recognized. Presently, a number of scientists around the world are examining the problems of building renovation considering various aspects.

3. Public buildings in Lithuania are renovated rather quickly, because a part of those (public institutions) have the ability to receive up to $100 \%$ of financial support for the repair and reconstruction of external walls and modernization of building energy systems from the EU structural support funds and the Government of the Republic of Lithuania.

4. The problems such as indoor air and floor temperature, relative humidity, air velocity, carbon dioxide concentrations not complying with the requirements for Lithuanian Hygiene Norm, high consumption heat, hot water preparation and electric power, great physical deterioration of buildings and poor aesthetic appearance of the building frequently can be faced in old buildings.
5. The performed in-kind investigation into public buildings in Lithuania disclose that wall heat transfer coefficients before wall insulation were more than 4 times greater than the normative value provided in building regulations imposed by the legal acts of the Republic of Lithuania while after insulation, the mean value of heat transfer coefficients satisfies requirements for building regulations stipulated by the law.

6. The examination of different insulation systems disclosed that better results were obtained applying external plastered composite thermal insulation systems, and worse results - employing external aeration heat-insulated systems. The results have been achieved due to better tightness of thermal wall insulation and lower thermal bridges.

7. The renovation of public buildings under examination revealed that the costs of heating and hot water preparation in different buildings decreased from $41.30 \%$ to $43.73 \%$.

\section{References}

Alanne, K. 2004. Selection of renovation actions using multicriteria "knapsack" model, Journal of Automation in Construction 13(3): 377-391. http://dx.doi.org/10.1016/j.autcon.2003.12.004

Cakmanus, I. 2007. Renovation of existing office buildings in regard to energy economy: an example from Ankara, Turkey, Journal of Building and Environment 42(3): 1348-1357. http://dx.doi.org/10.1016/j.buildenv.2005.11.007

Endriukaityte, A. 2009. Stipriai griežtinami reikalavimai pastatų energiniam efektyvumui [Energy efficiency requirements in buildings are tightening] [online], [cited 01 May 2012]. Available from Internet: http://www.paroc.lt/channels/lt/ about+us/news/news20091211.asp

ES parama [EU support] 2012. Projektu statistika [Project statistics] [online], [cited 29 April 2012]. Available from Internet: http://www.esparama.lt/barometras

EU Council. 2009. 2983th Council meeting. Press release. Energetics. Brussels. 17 p.

Eurostat 2012. Annual detailed enterprise statistics for construction [online], [cited 22 April 2012]. Available from Internet: http://appsso.eurostat.ec.europa.eu/nui/setupModifyTableLayout.do

Galvin, R. 2010. Thermal upgrades of existing homes in Germany: The building code, subsidies, and economic efficiency, Journal of Energy and Buildings 42(6): 834-844. http:// dx.doi.org/10.1016/j.enbuild.2009.12.004

Ignatavičius, Č.; Zavadskas, E. K.; Ustinovičius, L. 2007. Modernization of large-panel houses in Vilnius, in Proc. of the $9^{\text {th }}$ International conference on Modern Building Materials, Structures and Techniques, 16-18 May, 2007, Vilnius, Lithuania, 1: 258-264.

Ignatavičius, Č.; Ignatavičius, G.; Tuomas, E. 2002. 1997-2000 metu mokyklu renovacijos rezultatai [Results of school renovation 1997-2000]. Vilnius: Homo liber. 88 p. 
Leka (Lietuvos energetikos konsultantų asociacija) [Association of Lithuanian energy consultants]. 2012. Dienolaipsniai [Degree day's] [online], [cited 16 May 2012]. Available from Internet: http://www.leka.lt/index. php? content=pages\&lng=lt\&page_id=31\&news_id $=77$

Lietuvos higienos norma [Lithuanian Hygiene Norm] HN 42:2009 Gyvenamuju ir visuomeniniu pastatu patalpu mikroklimatas [Microclimate of the residential and public buildings]. Vilnius, 2009. 4 p.

Lietuvos higienos norma [Lithuanian Hygiene Norm] HN 75:2010 Istaiga, vykdanti ikimokyklinio ir (ar) priešmokyklinio ugdymo programą. Bendrieji sveikatos saugos reikalavimai [Institution executing preschool educational programs. General health and safety requirements]. Vilnius, 2010.14 p.

Lietuvos Respublikos statybos istatymas [Construction Law of the Republic of Lithuania]. Vilnius, 1996. 46 p.

Lietuvos Respublikos ūkio ministerija [Ministry of economy of the Republic of Lithuania]. 2012. ES parama. Energetikos priemones [EU support. Energy instruments] [online], [cited 01 April 2012]. Available from Internet: http://www.ukmin. lt/web/lt/es_parama/energetikos_priemones

Lietuvos statistikos departamentas [Department of Statistics of the Republic of Lithuania] 2012. Šalyje atlikta statybos darbu savo jegomis (be PVM), to meto kainomis [Construction work carried out within the country (VAT excl.) at current prices] [online], [cited 31 March 2012]. Available from Internet: http://db1.stat.gov.lt/statbank/selectvarval/saveselections.asp? MainTable $=$ M4060212\&PLanguage $=0 \&$ TableSt yle $=\&$ Buttons $=\&$ PXSId $=12947 \& I Q Y=\&$ TC $=\& S T=S T \&$ rvar $0=\& \operatorname{rvar} 1=\& \mathrm{rvar} 2=\& \mathrm{rvar} 3=\& \mathrm{rvar} 4=\& \operatorname{rvar} 5=\& \operatorname{rvar} 6=\& \mathrm{rva}$ $\mathrm{r} 7=$ \&rvar $8=\& \mathrm{rvar} 9=\& \operatorname{rvar} 10=\& \operatorname{rvar} 11=\& \operatorname{rvar} 12=\& \operatorname{rvar} 13$ $=\& \operatorname{rvar} 14=$

Matulis, T.; Ignatavičius, Č.; Volvačiovas, R. 2012. Pastatų fizinio nusidèvejimo vertinimo metodikos analizè ir jos panaudojimas tiriant ikimokyklinio ugdymo įstaigas [Analysis of buildings physical deterioration ranking methods and its practical use in researching preschool educational institutions], in Proc. of the $15^{\text {th }}$ Conference for junior researchers
Science - Future of Lithuania, 29-30 March, 2012, Vilnius, Lithuania, 7 p.

Nair, G.; Gustavsson, L.; Mahapatra, K. 2010. Factors influencing energy efficiency investments in existing Swedish residential buildings, Journal of Energy Policy 38(6): 2956-2963. http://dx.doi.org/10.1016/j.enpol.2010.01.033

Papadopoulos, A. M.; Theodosiou, T. G.; Karatzas, K. D. 2002. Feasibility of energy saving renovation measures in urban buildings: the impact of energy prices and the acceptable payback time criterion, Journal of Energy and Buildings 34(5): 455-466. http://dx.doi.org/10.1016/S0378-7788(01)00129-3

RSN 156-94 1995. Statybine klimatologija [Building climatology]. Respublikines statybos normos [Republican building regulation] Vilnius. $22 \mathrm{p}$.

STR 2.02.02:2004. Statybos techninis reglamentas [Technical regulation of construction] Visuomenines paskirties statiniai [Public buildings]. Vilnius, 2004. $17 \mathrm{p}$.

STR 2.05.01:2005. Statybos techninis reglamentas [Technical regulation of construction] Pastaty atitvaru šilumine technika [Thermal technique of building partition]. Vilnius, 2005. $112 \mathrm{p}$.

STR 2.09.04:2008. Statybos techninis reglamentas [Technical regulation of construction] Pastato šildymo sistemos galia. Šlumos poreikis šildymui [Capacity of heating system. The heat demand for heating]. Vilnius, 2008. 40 p.

Tommerup, H.; Svendsen, S. 2006. Energy savings in Danish residential building stock, Journal of Energy and Buildings 38(6): 618-626. http://dx.doi.org/10.1016/j.enbuild.2005.08.017

Tuominen, P., et al. 2012. Energy savings potential in buildings and overcoming market barriers in member states of the European Union, Journal of Energy and Buildings 51: 48-55. http://dx.doi.org/10.1016/j.enbuild.2012.04.015

Weiss, J.; Dunkelberg, E.; Vogelpohl, T. 2012. Improving policy instruments to better tap into homeowner refurbishment potential: lessons learned from a case study in Germany, Journal of Energy Policy 44: 406-415. http://dx.doi.org/10.1016/j.enpol.2012.02.006 


\section{VISUOMENINIŲ PASTATU ATNAUJINIMO PROBLEMOS NAGRINĖJIMAS REMIANTIS NATÜRINIAIS SIENŲ ŠILUMOS PERDAVIMO KOEFICIENTŲ TYRIMAIS}

\section{R. Volvačiovas, Z. Turskis, Č. Ignatavičius, L. Ustinovičius, A. Ruzgys}

Santrauka. Straipsnyje trumpai apžvelgta pastatų energinio efektyvumo problematika, visuomeninių pastatų atnaujinimo situacija Lietuvoje, pateikiami keli užsienio valstybių mokslininkų darbų, kuriuose nagrinejjama pastatų atnaujinimo tematika, pavyzdžiai. Be praktinių pavyzdžių, nurodomi veiksniai, lemiantys visuomeninės paskirties pastatų atnaujinimą. Taip pat pateikiami visuomeninés paskirties pastatų sienų šilumos perdavimo koeficientų tyrimų, atliktų naudojant laboratorinę i̇rangą, rezultatai, ištyrus kelis visuomeninès paskirties pastatus Lietuvoje prieš ir po pastatų atnaujinimo. Palyginta išorinė tinkuojama sudètinė termoizoliacinė sistema su išorine vẻdinamąja termoizoliacine sistema, apibendrinta nagrinejjamų pastatų sąnaudų šildyti ir karštam vandeniui ruošti ekonominẻ nauda prieš ir po pastatų atnaujinimo taikant dienolaipsnių metodiką.

Reikšminiai žodžiai: visuomeninis pastatas, pastato atnaujinimas, pastato modernizavimas, ekonominė nauda, išorinė atitvara, šilumos perdavimo koeficientas, natūriniai tyrimai, dienolaipsnių metodika.

Robertas VOLVAČIOVAS. PhD student at the Department of Construction Technology and Management, Faculty of Civil Engineering, Vilnius Gediminas Technical University (VGTU). Research interests: building technology and management, renovation of buildings.

Zenonas TURSKIS. Doctor of Technical Science, Senior Research fellow of Construction Technology and Management Laboratory, Faculty of Civil Engineering, Vilnius Gediminas Technical University (VGTU). Research interests: building technology and management, decision-making theory, computer-aided automation in design, expert systems.

Česlovas IGNATAVIČIUS. Doctor of Technical Science, Associate Professor, Senior Research fellow at the Department of Construction Technology and Management, Faculty of Civil Engineering Vilnius Gediminas Technical University (VGTU). Research interests: construction defectology and modernization of buildings.

Leonas USTINOVIČIUS. Doctor Habil, Professor, Chairman of the Laboratory of Construction Technology and Management, Faculty of Civil Engineering, Vilnius Gediminas Technical University (VGTU). Research interests: building technology and management, decision-making theory, automation in design, expert systems.

Audrius RUZGYS. Postgraduate at the Department of Construction Technology and Management, Faculty of Civil Engineering, Vilnius Gediminas Technical University (VGTU). Research interests: building technology and management, renovation of buildings. 